\title{
Place of agritourism in a balanced development of rural areas
}

\author{
Hanna Tschirschnitz
}

University of Warmia and Mazury, Oczapowskiego 2, 10-957 Olsztyn, Poland

e-mail: htschirschnitz1@interia.pl

\begin{abstract}
Short time prognosis for period between 2000 and 2020 assumes that deep transformation has to be performed at rural areas of Poland. The transformation process will cover of fields of rural development from agricultural sector, demography, sources of income, cultural life, etc. The significance of agriculture has been constantly as a trustee of big share of natural resources of Poland. Contrary to this in the structure of employment and in income of rural population agriculture will play a smaller role. It is evident that the main source of income will become service of agricultural sector.

Multifunctional management of rural areas combined with rules of sustainable development can be very effective tool for protection of the natural environment which in large areas of Poland has unique values estimated as the highest degree of biodiversity in whole Europe is a tool for improvement of economical position of rural population.

Sustainable development is aimed at protection of and maintenance of natural values what in indirect way can lead to improve of quality of life at rural areas. The important part of such attitude is agrotourism which is directly connected to utilization of environmental values of rural regions and it is a form of spending leisure time at the farm for wide public.

Attractions connected with staying at rural environment are significant elements of management of rural landscape. Besides economical benefits effect of synergy should be mentioned which is seen as better care of natural environment and aesthetic values of surroundings.
\end{abstract}

Key words: agroturism, multifunctional rural areas, sustainable development.

\section{Introduction}

As a result of dynamic development of non-agricultural and accompanying processes, resolving issues of multidirectional rural development are becoming increasingly important.

The harmony between the needs of social, economic and natural sciences is extremely important, especially in conflict areas, where areas of human activity are directly next to natural areas, and the form and the results of this activity are dependent on nature (Kisiel et al. 2007; Dubel 2001).

Nowadays, the role of a new approach to rural development is increasing. As a result of political transition (Adamowicz 2004) the areas which by now were characterized by monofunctionality (production of food and feed), are facing the problem of economic, social, spatial and environmental degradation. When implementing the new features, very important benefits are: balance in the environment, harmony and balance of all the functions of rural areas (Żebrowski 2004).

The increase of the competitiveness of agriculture and the efficient production of agricultural produce cause that a smaller number of farms can maintain only from agriculture, as they are unable to withstand the economic pressure. Therefore, the village has to reconcile a variety of activities. It ceases to be just a place to produce raw materials, and becomes an integrated place, where in addition to agriculture, different branch developing and manufacturing services are being developed (Piekarska 2004; Adamowicz 2004). 
Rural areas not only to meet the social tasks, but also economic and environmental ones, therefore multifunctioning of rural areas has to become a major goal of agricultural policy (Cymerman et al. 2004).

Following the EU in Poland, the issue that appears more often is the one of the multifunctional development of rural areas. The strategy for Poland is that, in addition to agriculture on rural areas, tourism, including and agritourism will be developed (Młynarczyk 2002).

The aim of this work is to present opportunities for developing tourism in rural areas and the benefits it can bring to agricultural activity.

\section{The natural environment and the development of agritourism}

The effects of agricultural activities in rural areas mainly depend on the natural environment, although the regenerative capacity is subject to degradation as a result of the impact of external and internal factors. Farmers have used the environment, the forces of nature to produce food and agricultural commodities. As a result of their activities environmental changes were accumulated, which was increased along with the process of intensification and concentration of agricultural production. Superposition of all the changes caused environmental degradation resulting from industrial development and urbanization, and associated with these processes unplanned, short-sighted intervention in nature (Kisiel et al. 2007).

Taking into account the plans for rural development, balanced development which aims to better meet the physical and psychological human needs, through its proper position relative to the natural environment, it is possible to avoid infringement, in an irreversible way, of the environment surrounding the man while reconciling economics and the laws of nature (Borys 1999; Hałasa \& Rumianowska 2000).

The task of balanced rural development in the protection of nature and health is the proper configuration of rural landscapes and their care, regeneration and storage of water resources, creating attractive places to rest, recreation, nutrition and treatment and effective protection of high quality natural environment, with unique on a continental scale landscape and cultural values, and the richest biological diversity in Europe (Kisiel et al. 2007; Piekarska 2004).

The balanced development will favor the rational dispersal of agriculture structure and non-agricultural economic activities and it may be mainly implemented through appropriate land use, taking into account the principles and the need to protect the environment, including enabling behavior and functioning of ecosystems. This indicates the need for the formulation and implementation of new spa- tial order coupled with environmental governance, social and economic policies within a particular region (Piekarska 2004).

Tourism is now one of the fastest growing industries in the world, where natural environmental resources are used and on the other hand, farmers through their work shape the environment (Młynarczyk 2002).

Agritourism is included in the definition of rural tourism, is a form of recreation in the areas of "real country" that covers many types of activities: hiking tours, active, cultural tourism, etc. Drzewiecki (1995) defines agritourism as "a form of relaxation which takes place in rural agricultural nature, which has accommodation facilities and recreational activities associated with a farm or their equivalent and its environment (natural, manufacturing, service) (Marks et al. 2002; Woźniak \& Kusz 2002).

Agritourism is based on the principles of balanced or sustainable development aiming at exploiting the earth's resources in a way to meet the needs of present and future generations without undermining and destroying their natural resources (Iwicki 1998).

Rural tourism, agritourism too, have already made significant organizational traditions in many European countries. For many years, among the leading countries were France, Germany, Ireland, Austria and Switzerland. Spending free time in rural areas in Poland is not something new. Quite common were holidays in the Tatra highlands at the turn of the eighteenth and nineteenth centuries (Młynarczyk 2002).

Agritourism is a form of relaxation which provide the potential interested the attractions related to the presence in rural areas, and also significantly shapes the landscape of the village. Committed to that tourists not only look for the relevant farm tourism, peace and tranquility, but also the additional experiences and information related to the region (Woźniak 2002).

A tourist wishing to spend their holidays in the countryside, may, at least in part, blend in a traditional rural lifestyle, although providing potential visitors all the comforts and variety of attractions might cause some problems for farm owners (Młynarczyk 2002).

Agritourism, in addition to well-prepared base of accommodation and residence, to a great extend is based on attractive natural environment (Marks \& Marks 2002). The biggest challenge is to preserve and protect these values. Very often most valuable natural areas and facilities are also the most attractive tourist destinations. Sometimes on these areas can be found small areas of primary or natural landscapes. They are mostly accompanied by harmoniously shaped cultural landscapes with a small share of urban areas. To such macro-regions belong for example the Mazury Lake District. Therefore, the harmonious development of agritourism means to reconcile environmental protection with the tourists and local communities needs. Hence, the 
balanced tourism is based mainly on adapting the forms of tourism activities to the natural and social conditions (Młynarczyk 2002).

Leisure use is one of the additional lines used for rural areas and Warmia-Mazury region is especially predestined for such a use. Factors that attract tourists are the natural scenery, a relatively small degradation of the natural environment, an attractive structure of land use (forest cover, rich grasslands in the structure of agricultural land, water) and well-preserved cultural monuments (Młynarczyk 2002).

Very important is the impact that tourism has on the living standard of rural population and it becomes the centerpiece of the multioccupation activity and already existing employment consolidation. Increasingly, tourism determines the value of the area becoming an additional element of non-agricultural activity.

Benefits include:

- increase in the number of jobs,

- development of services both directly and indirectly linked to tourism,

- use of local agricultural products, horticulture, fishing,

- preservation and protection of the landscape,

- conservation of monuments,

- development of technical infrastructure and raising housing standard (Piekarska 2004).

Moreover, rural tourism can improve a number of elements such as: the quantity and quality of services, quality of rural residents life, and ways of spending their free time (Passaris et al. 2002; Witkowska-Dąbrowska \& Ziajka 2002).

Rural tourism does not heal agriculture, but is able to significantly improve the situation of rural population. Another possibility is to use the natural riches to the development of ecological tourism, which aims to care for the environment and aesthetics of the entire environment (Piekarska 2004).

\section{Conclusions}

Poland has the right conditions for the implementation of a modern model of the village, because the Polish rural areas are one of the least deprived in Europe. To maintain this status and to prevent excessive pollution, it is necessary to apply, in practice, the principles of a balanced development. a variety of natural resources, farming systems, folk culture and national tradition are the key factors of multidirectional development.

Recapitulate: Agritourism is the division of the economy, which is particularly suitable for implementation in rural areas in accordance with the principles of a balanced development.

\section{References}

Adamowicz M., 2004, Wielofunkcyjność rolnictwa jako podstawa przewartościowań $\mathrm{w}$ polityce regionalnej [Multifunctionality of agriculture as the basis for revaluation in the regional Policy], Wieś i rolnictwo [Rural areas and agriculture] 4 (125): 9-27.

Borys T., 1999, Wskaźniki ekorozwoju [Sustainability Indicators], Wydawnictwo Ekonomia i Środowisko, Białystok.

Cymerman R., Bajerowski T., Nowak A., Podciborski T. \& Biłozor A., 2004, Rewitalizacja obszarów wiejskich [Rural areas revitalisation], Wojewódzki Fundusz Ochrony Środowiska i Gospodarki Wodnej, Olsztyn: 7-23.

Drzewiecki M., 1995, Agroturysyka [Agritourism], Instytut Wydawniczy „Świadectwo”, Bydgoszcz.

Dubel K., 2001, Ochrona i kształtowanie środowiska [Environmental Conservation and Management], Fundacja Centrum Edukacji Ekologicznej Wsi, Krosno.

Hałasa J. M. \& Rumianowska I., 2000, Koncepcja ekorozwoju rolnictwa na tle zmian strukturalnych regionu wałbrzyskiego [The concept of agriculture sustainable development on the background of Walbrzych region structural changes], [in:] H. Sasinowski (ed.), Ekorozwój w polityce regionalnej [Sustainability in regional policy], Wydawnictwo Politechniki Białostockiej, Białystok: 171-181.

Iwicki S., 1998, Turystyka w zrównoważonym rozwoju obszarów pojeziernych [Tourism in a balanced development of post-lake areas], Akademia Techniczno-Rolnicza, Bydgoszcz.

Kisiel R., Marks-Bielecka R. \& Lizińska W., 2007, Wybrane aspekty zrównoważonego rozwoju obszarów wiejskich [Selected aspects of a balanced rural development], Folia Universitatis Agriculturae Stetinensis, Oeconomica 254 (47): 105-112.

Marks M. \& Marks E., 2002, Agroturystyka na Warmii i Mazurach a problemy ochrony przyrody [Warmia and Mazury agritourism and issues of environmental protection], [in:] K. Młynarczyk, M. Marks (eds.), Agroturystyka $\mathrm{w}$ teorii praktyce [Agritourism in theory and practice], Wydawnictwo UWM, Olsztyn: 175-182.

Marks M., Marks E. \& Młynarczyk K., 2002, Znaczenie agroturystyki w rozwoju obszarów wiejskich [The importance of agritourism in rural development], [in:] K. Młynarczyk (ed.), Agroturystyka [Agritourism], Wydawnictwo UWM, Olsztyn: 12-30.

Młynarczyk K., 2002, Wprowadzenie [Introduction], [in:] K. Młynarczyk (ed.), Agroturystyka [Agritourism], Wydawnictwo UWM, Olsztyn: 7-12.

Passaris S., Sokólska J. \& Vinaver K., 2002, Rozwój obszarów wiejskich i turystyka [Rural development and 
tourism], Wydawnictwo Narodowej Fundacji Ochrony Środowiska, Białystok-Paryż.

Piekarska E., 2004, Pozarolniczy rozwój terenów niezurbanizowanych Warmii i Mazur [Non-agricultural development of Warmia and Mazury non-urbanized areas], Wojewódzki Fundusz Ochrony Środowiska i Gospodarki Wodnej, Olsztyn: 35-51.

Witkowska-Dąbrowska M. \& Ziajka F., 2002, Wykorzystanie studiów uwarunkowań i kierunków rozwoju zagospodarowania przestrzennego do inspirowania rozwoju agroturystyki [Using studies of conditions and directions of planning development to inspire the tourism development], [in:] K. Młynarczyk, M. Marks (eds.), Agroturysyka w teorii praktyce [Agritourism in theory and practice], Wydawnictwo UWM, Olsztyn: 98-104.
Woźniak M., 2002, Wpływ agroturystyki na architekturę krajobrazu obszarów wiejskich [The impact of agritourism on the rural landscape architecture], Fragmenta Agronomica XIX, 1 (73): 194-200.

Woźniak M. \& Kusz D., 2002, Miejsce agroturystyki w formach spędzania wolnego czasu [Place of agritourism in the forms of spending spare time], [in:] K. Młynarczyk, M. Marks (eds.), Agroturysyka w teorii praktyce [Agritourism in theory and practice], Wydawnictwo UWM, Olsztyn: 114-121.

Żebrowski W., 2004, Rewitalizacja obszarów wiejskich jako wizja ich rozwoju [Revitalization of rural areas as a vision of their development], Wojewódzki Fundusz Ochrony Środowiska i Gospodarki Wodnej, Olsztyn: 163-170. 